\title{
Severe Variant of Sickle Cell Intrahepatic Cholestasis a Difficult Approach Diagnosis Clinical Presentation and Outcome in Adult Population in the Congo
}

\author{
Lydie Ocini Ngolet ${ }^{*}$, Vulliez Renucci Nkounkou${ }^{1}$, Blaise Atipo Ibara ${ }^{2}$, Alexis Elira Dokekias ${ }^{1}$ \\ ${ }^{1}$ Department of Medical Hematology, University Hospital of Brazzaville, Brazzaville, The Republic of the Congo \\ ${ }^{2}$ Department of Internal Medicine and Gastroenterology Unit, University Hospital of Brazzaville, Brazzaville, The Republic of the Congo \\ Email: *lngolet@yahoo.fr
}

How to cite this paper: Ngolet, L.O., Nkounkou, V.R., Atipo Ibara, B. and Elira Dokekias, A. (2020) Severe Variant of Sickle Cell Intrahepatic Cholestasis a Difficult Approach Diagnosis Clinical Presentation and Outcome in Adult Population in the Congo. Open Journal of Blood Diseases, 10, 41-47. https://doi.org/10.4236/ojbd.2020.102005

Received: April 30, 2020

Accepted: May 26, 2020

Published: May 29, 2020

Copyright $\odot 2020$ by author(s) and Scientific Research Publishing Inc. This work is licensed under the Creative Commons Attribution International License (CC BY 4.0).

http://creativecommons.org/licenses/by/4.0/

(c) (i) Open Access

\begin{abstract}
Background: There are no consensual diagnosis criteria to make diagnosis of sickle cell intrahepatic cholestasis and identify its 2 variants. Here we delineate the frequency of the complication in its severe form and describe its clinical features. Methods: We included in the study all the patients with sickle cell disease who were presenting fever, jaundice, pain in the upper right quadrant and filling up the biological criteria of the severe sickle cell intrahepatic cholestasis (serum direct bilirubin $\geq 78.5 \mathrm{mg} / \mathrm{dL}$ ). Patients with evidence of viral hepatitis or gallstones were not included in the study. Results: Sixty-two patients with an average age of 21.5 years (range 18 and 25 years) meet the inclusion criteria, minimum serum direct bilirubin: 82 versus 528 for the maximum. The liver cytolysis was major and ranged from 310 to 1550 UI/L. Forty-nine patients (83.9\%) did not develop any organ failure. The symptoms and biological abnormalities resolved with supportive treatment within 7 days. The global lethality was $16.1 \%$ associated with liver failure. Conclusion: Severe sickle cell intrahepatic cholestasis is more frequent than we thought and was mainly represented by borderline clinical feature. Early intervention may reduce the progression to organ failure stage and ultimate death.
\end{abstract}

\section{Keywords}

Sickle Cell Disease, Serum Direct Bilirubin, Borderline Clinical Feature 


\section{Introduction}

Sickle cell disease (SCD) is the most common worldwide genetic hemoglobin disorder. In the Congo, about $20 \%$ of the population present the sickle cell trait while $1.25 \%$ develop the disease [1]. The abnormal hemoglobin, hemoglobin $S$ ( $\mathrm{HbS}$ ), in deoxygenated environment binds to other Hbs molecules forming long polymers that distort red cells causing sickling and hemolysis that lead to acute and chronic complications. Hepatobiliary complications of sickle cell disease encompass a range of chronic and acute hepatic complications caused by multiple mechanisms among them, sickling and chronic hemolysis. Sickle cell hepatopathy is an acute liver complication of SCD. It is a generic name that includes multiple syndromes that are: acute hepatic sequestration, acute hepatic sickle cell crisis (AHSCC) and a sickle cell intrahepatic cholestasis (SCIC) [2]. They all share similar clinical presentations but differ by the extension of the histologic lesions related to sickling and the severity of biochemical abnormalities [2]. SCIC is an uncommon syndrome which is classified into two categories or types that require early diagnosis for early intervention to avoid a progression toward the severe type of the syndrome [3]. Indeed, the severe type is potentially fatal and requires immediate treatment. However, the severe variant has different clinical presentation which in the absence of standard criteria for its diagnosis can delay its management. The aim of our study is to review clinical and biological features of patients with severe type of SCIC but show, without clear guidance, the challenge of reaching a formal diagnosis.

\section{Materials and Methods}

\subsection{Ethical Considerations}

The study was approved by the ethic committee before data collection was initiated: CERSSA N ${ }^{\circ} 0189 / 2015$. The study was conducted in compliance with the ethical standards of the responsible institution on human subjects as well as with the Helsinki Declaration.

- Study design and population

We conducted a cross-sectional study during three years in the hematology department in the University hospital in Brazzaville which is a tertiary and biggest healthcare facility in the Congo.

Inclusion criteria were the following:

- Patients aged over 18 years with fever and pain in the right upper quadrant;

- Patients with HbSS genotype;

- Plasma liver enzymes level over 300 UI;

- Patients free of viral hepatitis;

- No evidence of extrahepatic obstruction, gallbladder or hepatic sequestration at the abdominal ultrasound.

For each patient we collected:

- epidemiological data: age, gender and self-medication; 
- clinical feature;

- biological findings;

- outcome: clinical and biological findings sample were collected from patients at the admission and 10 days later.

We did not include subject with evidence of extrahepatic obstruction, gallbladder or hepatic sequestration, as well those with plasma liver enzymes below 300 UI.

Case definition

The diagnosis of SCIC was based on the presence of the following criteria:

1) clinical: fever, upper right quadrant pain, hepatomegaly, jaundice;

2) biological: serum direct bilirubinemia over $78.5 \mathrm{mg} / \mathrm{L}$;

3) imagery: liver ultrasound: enlarged liver, no gallbladder nor biliary obstruction.

\subsection{Statistical Analysis}

Entry and analysis of all data were done using the package CSPRO 3. Data are expressed as mean and percentage.

\section{Results}

During the period of the study, 680 adult patients with SCD were admitted in the hematology department. Among them 143 (21.02\%) had developed a hepatobiliary syndrome and 62 (9.1\%) SCIC.

There were 25 men (40.30\%) and 37 women (59.70\%) with a sex-ratio of 1.48 . The mean age was 21.5 years (extreme 18 and 25 years). Half of the patients (56.5\%) were aged between 18 and 22 years old.

All patients reported self-medication. The nature of the medications was: acetaminophen (18.51\%), ibuprofen (27.78\%), acetaminophen + ibuprofen (43.51\%), chlorhydrate of tramadol (9.26\%) and phloroglucinol (0.83\%).

At admission SCIC was associated with vaso-occlusive crisis (66\%), acute hemolytic anemia crisis (33\%), malaria and pneumonia (33.87\%) respectively, urinary tract infection (19.33\%) and physical factors (12.90\%).

Treatment consisted on parenteral hydration (100\%), pain killer (66\%), blood transfusion (76\%) antibiotics (59.7\%) and antimalarial (19.4\%).

The biological characteristics of patients with SCIC at the admission and outcome are detailed in Table 1.

Thirteen patients (16.1\%) developed liver failure with a PTT below 70\% (extremes $38 \%$ and $60 \%$ ). They all died (16.1\%) within 4 days (extremes 3 and 7 days). For patients that had better outcome, the symptoms and laboratory findings resolve spontaneously within 7 days (extremes 3 and 14 days).

\section{Discussion}

SCIC is an emergency medical condition. It is a severe variant of AHSCC that requires immediate and appropriate care [3]. It is an uncommon and fatal acute 
Table 1. Biological characteristics of patients with severe type sickle cell intrahepatic cholestasis.

\begin{tabular}{|c|c|c|}
\hline & At admission $(n=62)$ & After the crisis $(n=49)$ \\
\hline Hemoglobin (g/dL) & $\begin{array}{c}8.34 \\
(7.50-9.60)\end{array}$ & $\begin{array}{c}8.25 \\
(8-10.9)\end{array}$ \\
\hline WBC (Giga/L) & $\begin{array}{c}15.07 \\
(10.30-24.00)\end{array}$ & $\begin{array}{c}14.37 \\
(10.5-26.00)\end{array}$ \\
\hline Granulocytes (\%) & $\begin{array}{c}53.45 \\
(40-75)\end{array}$ & $\begin{array}{c}50.35 \\
(40-80)\end{array}$ \\
\hline $\operatorname{AST}(\mathrm{U} / \mathrm{L})$ & $\begin{array}{c}978.34 \\
(410-3820)\end{array}$ & $\begin{array}{c}29.80 \\
(22-35)\end{array}$ \\
\hline $\operatorname{ALT}(\mathrm{U} / \mathrm{L})$ & $\begin{array}{c}729.56 \\
(310-1550)\end{array}$ & $\begin{array}{c}28.73 \\
(15-37)\end{array}$ \\
\hline $\mathrm{PAL}(\mathrm{U} / \mathrm{L})$ & $\begin{array}{c}406.32 \\
(300-2370)\end{array}$ & $\begin{array}{c}99.93 \\
(96-105)\end{array}$ \\
\hline $\mathrm{LDH}(\mathrm{U} / \mathrm{L})$ & $\begin{array}{c}306.37 \\
(230-405)\end{array}$ & $\begin{array}{c}249.07 \\
(230-300)\end{array}$ \\
\hline$\gamma \mathrm{GT}(\mathrm{U} / \mathrm{L})$ & $\begin{array}{c}74.67 \\
(40-100)\end{array}$ & $\begin{array}{c}14.23 \\
(7.5-39)\end{array}$ \\
\hline Total bilirubin (mg/dL) & $\begin{array}{c}153.24 \\
(95-855)\end{array}$ & $\begin{array}{c}7.67 \\
(5.5-9.5)\end{array}$ \\
\hline Direct bilirubin (mg/dL) & $\begin{array}{c}94.92 \\
(82-528)\end{array}$ & $\begin{array}{c}2.06 \\
(1-3)\end{array}$ \\
\hline Creatinine $(\mathrm{mg} / \mathrm{L})$ & $\begin{array}{c}9.89 \\
(3-14)\end{array}$ & $\begin{array}{c}9.53 \\
(6-13)\end{array}$ \\
\hline РTT\% & $\begin{array}{c}78 \% \\
(38-100)\end{array}$ & $\begin{array}{c}85 \\
(70-100)\end{array}$ \\
\hline
\end{tabular}

hepatic complication that affects patients with sickle cell disease or sickle cell-beta thalassemia. Ahn and Diggs have identified two distinct types of SCIC based on different level of the serum direct bilirubinemia and clinical feature [3] [4]. The mild type, is self-limited without severe hepatic dysfunction, the serum direct bilirubin level ranges from $10-30 \mathrm{mg} / \mathrm{dL}$. The severe type, is a life threatening emergency medical condition that is usually fatal with a direct bilirubin level greater than $30 \mathrm{mg} / \mathrm{dL}$. It is characterized by deep jaundice, fulminant liver failure with coagulopathy and encephalopathy [4]. A French study has described a third type based on the level of liver enzyme [5]. The distinction between the two groups is not clear and to date there is no consensus for the diagnosis of the SCIC and its variant [6].

Sixty-two patients $(9.1 \%)$ of a cohort of 636 had probably developed a severe type of SCIC which is the highest frequency reported [4]. They were young adults. The literature review from 2001 to 2020 has shown that the incidence is higher in the pediatric population, but less aggressive if we compare with the adult one [7]. Congolese patients presented an aggressive course. Indeed, biological studies revealed major hyperbilirubinemia $(94.92 \mathrm{mg} / \mathrm{dL})$ and liver dysfunction, which confirms the diagnosis of the SCIC in its severe variant. Ultra- 
sound did not show any portal hypertension while Lorraine B et al., accounted it in $42 \%$ [5].

In contrast to the data reported, less than a quarter of our population $(16.2 \%)$ had developed a coagulopathy, which is unusual for the severe variant [4] [8] [9] [10]. According to authors, exchange transfusion is the only effective treatment for severe SCIC [6] [11]. We obtained reversal liver function and successful outcome in $83.8 \%$ with simple red blood cell transfusion. To date only one known case survived without exchange transfusion [12]. We did not find any relationship between self-medication and development of the syndrome. Cholecystitis and choledocholithiasis were not in the differential diagnosis as they were not included in the study. Three differential diagnoses were discussed. Severe acute sickle cell hepatic crisis is among one of them [5]. It is a variant of the acute sickle cell hepatic crisis. Liver enzyme level is usually over $300 \mathrm{UI} / \mathrm{L}$ while serum bilirubin level is variable. Coagulopathy was noticed in all cases. However, there was a selection bias since $68.7 \%$ of the population studied had a chronic hepatopathy [5]. Middle or moderate type SCIC is the second differential diagnosis. The presentation can be benign with relatively few symptoms. It differs from our cohort by the serum direct bilirubinemia level which is usually inferior to 28 $\mathrm{mg} / \mathrm{dL}$. But it has in common: the outcome, the low coagulopathy, lethality rate and the management strategy. The third diagnosis is the benign hyperbilirubinemia. It shares a common feature such as the high serum bilirubinemia level but differs with the presence of hepatobiliary dysfunction.

Severe acute sickle cell crisis or severe variant of SCIC, our patients developed intermediate clinical feature of sickle cell hepatopathy with major hyperbilirubinemia which if they are not handled at the early stage, could rapidly evolve to organs failure and then death.

Our cross-sectional study has some limitations. The study was conducted in one center. However, the teaching hospital is the biggest health care facility in Brazzaville, capital of the country. Our cohort is then quite representative of Adults with sickle cell disease in Brazzaville. Iron overload is suggested to cause abnormal liver enzyme level [13]. It would have been interested to measure the plasma ferritin level to our patients. Finally, we collected data in our records, mistakes during the reporting are potentially possible. Despite those limits our study had enlightened the high frequency of the SCIC among sickle cell patients in the Congo and the difficulty to distinguish its variant.

\section{Conclusion}

SCIC is an acute hepatobiliary syndrome that has multiple clinical presentations. Diagnosis should be made after excluding other hepatobiliary syndromes. The borderline between the middle and severe types is not stated. Intermediate clinical feature with hyperbilirubinemia should-in our context with limited capacity-be handled as the severe form of the SCIC. In the absence of blood exchange, simple transfusion should be offered when needed without delay to patients. 


\section{Funding Statement}

Research and publication of the article are not supported by any agency, non-governmental organization or institute.

\section{Data Availability Statement}

Data supporting the results reported are available in the published article, are available in the Hematology Unit's (Brazzaville University Hospital) archived data library.

\section{Acknowledgements}

The authors wish to thank Mr. Oscar Ngole for his help in editing the manuscript.

\section{Authors' Contributions}

Lydie Ocini Ngolet drafted the paper, Vulliez Renucci Nkounkou, Irenée Atipo Ibara and Alexis Elira Dokekias helped to the diagnosis. All authors read and approved the final paper.

\section{Informed Consent}

It is a retrospective study, data obtained on medical records. Ethical clearance: CERSSA N ${ }^{\circ} 0189 / 2015$.

\section{Conflicts of Interest}

The authors declare no conflicts of interest regarding the publication of this paper.

\section{References}

[1] Mouelet, R., Boukila, V., Fourcade, V., Feingold, J. and Galactéros, F. (1999) Sickle Cell Disease in Brazzaville, Congo: Genetical, Hematological and Clinical Aspects. Acta Haematologica, 101, 178-184. https://doi.org/10.1159/000040950

[2] Banerjee, S., Owen, C. and Chopra, S. (2001) Sickle Cell Hepatopathy. Hepatology, 33, 1021-1028. https://doi.org/10.1053/jhep.2001.24114

[3] Diggs, L.W. (1992) Anatomical Lesions in Sickle Cell Hemoglobinopzthies-Liver. In: Mankad, V.N. and Moore, R.B., Eds., Sickle Cell Disease: Pathophysiology, Diagnosis and Management, Praeger Publisher, Wesport, CT, 161-163.

[4] Hyunah, A., Li, C.S. and Wang, W. (2005) Sickle Cell Hepatopathy: Clinical Presentation, Treatment and Outcome in Pediatric and Adult Patients. Pediatric Blood Cancer, 45, 184-190. https://doi.org/10.1002/pbc.20317

[5] Lorrain, B., Gellen Dautremer, J., Batolucci, P. et al. (2013) Manifestations hépatiques sévères de la drépanocytose. Etude rétrospective monocentrique de 19 cas. La Revue de médecine interne, 345, A22-A29. https://doi.org/10.1016/j.revmed.2013.10.100

[6] Marti-Cavarjal, A.J. and Marti-Amarista, C.E. (2017) Intervention for Treating Intrahepatic Cholestasis in People with Sickle Cell Disease. Cochrane Database Sys- 
tematic Review, No. 7, Article No. CD010985.

https://doi.org/10.1002/14651858.CD010985.pub3

[7] Papafragkakis, H., Ona, M.A., Changela, K., et al. (2014) Acute Liver Function Decompensation in a Patient with Sickle Cell Disease Managed with Exchange Transfusion and Endoscopic Retrograde Cholangiography. Therapeutic Advance in Gastroenterology, 7, 217-223. https://doi.org/10.1177/1756283X14530781

[8] Kwun Lui, S., Krasinskas, A., Shah, R. and Tracht, J.M. (2019) Liver Transportation for Acute Intrahepatic Cholestasis in Sickle Cell Disease: Clinical and Histopathologic Feature of a Rare Case. International Journal of Surgical Pathology, 27, 411-417. https://doi.org/10.1177/1066896918798467

[9] Brunetta, D.M., Silva-Pinto, A.C., do Carmin Favarin de Macedo, M., Bassi, S.C., Piccolo Feliciano, J.V., Ribeiro, F.B., et al. (2011) Intrahepatic Cholestasis in Sickle Cell Disease: A Case Report. Anemia, 2011, Article ID: 975731.

https://doi.org/10.1155/2011/975731

[10] Alkhayyat, M., Abou Saleh, M., Zmaili, M., et al. (2020) Successful Liver Transplantation for Acute Sickle Cell Intrahepatic Cholestatis: A Case Report and Review of the Literature. World Journal of Hepatology, 12, 108-115.

https://doi.org/10.4254/wjh.v12.i3.108

[11] Hosiriluck, N., Rassameehiran, S., Argueta, E. and Tijani, L. (2014) Reversal of Liver Function without Exchange Transfusion in Sickle Cell Intrahepatic Cholestasis. Proceedings (Baylor University. Medical Center), 27, 361-363. https://doi.org/10.1080/08998280.2014.11929160

[12] Albano de Guimaraes, J. and dos Santos Silva, L.C. (2017) Sickle Cell Intrahepatic Cholestasis Unresponsive to Exchange Blood Transfusion: A Case Report. Revista Brasileira de Hematologia e Hemoterapia, 39, 163-166. https://doi.org/10.1016/j.bjhh.2017.02.006

[13] Allali, S., De Montalembert, M., Brousse, V., et al. (2019) Hepatobiliary Complications in Children with Sickle Cell Disease: A Retrospective Review of medical Records from 616 Patients. Journal of Clinical Medicine, 8, 1481. https://doi.org/10.3390/jcm8091481 